logos_i_ethos_2015_1_(38), s. 25-40

DOI: http://dx.doi.org/10.15633/lie.1043

Krzysztof Kunisz

Uniwersytet Pedagogiczny w Krakowie

\title{
Kultura, moralność oraz duchowość w filozofii Anny Teresy Tymienieckiej
}

Niniejszy artykuł traktuje o niektórych dokonaniach filozoficznych Anny Teresy Tymienieckiej w odniesieniu do idei onto-poiesis. Szczególne miejsce $\mathrm{w}$ jej systemie myśle-

Krzysztof Kunisz - doktorant filozofii na Wydziale Humanistycznym Uniwersytetu Pedagogicznego w Krakowie. Przygotowuje pracę doktorską o filozofii Anny-Teresy Tymienieckiej. Główne zainteresowania naukowe: fenomenologia, psychologia i filozofia religii. nia zajmują takie wymiary typowo ludzkiej działalności w świecie, jak na przykład kultura, moralność i duchowość - celem tej pracy będzie opisanie tych wątków w jej twórczości.

Najpierw przedstawiona zostanie sylwetka Anny Teresy Tymienieckiej oraz podstawowy zarys jej filozofii. Potem autor tego artykułu opisze koncepcję aktu kreatywnego w twórczości Tymienieckiej w odniesieniu do krytyki tradycyjnej fenomenologii. Następnie zarysuje problematykę miejsca ludzkiej kultury w rzeczywistości rozumianej jako onto-poiesis oraz koncepcję moralności wyrażającą napięcie pomiędzy eidos a ethos w świadomości człowieka. Na koniec zostanie ukazany duchowy wymiar funkcjonowania człowieka, który w filozofii Tymienieckiej wyraża się poprzez pęd ku transcendencji.

\section{Sylwetka Anny Teresy Tymienieckiej ${ }^{1}$}

Anna Teresa Tymieniecka urodziła się 28 lipca 1923 roku w Polsce, we wsi Marianowo. Skończyła gimnazjum klasyczne w Zawierciu

1 Informacje na temat biografii A. T. Tymienieckiej pochodzą z następujących źródeł: J. Szmyd, Międzynarodowy Kongres Filozoficzny dla uczczenia dorobku twórczego A. Tymienieckiej, 
oraz liceum w Sosnowcu. Studiowała filozofię w latach 1945-1947 na Uniwersytecie Jagiellońskim, gdzie uczestniczyła w seminarium filozoficznym Romana Ingardena, oraz malarstwo w krakowskiej Akademii Sztuk Pięknych. Po studiach nadal przyjaźniła się z Ingardenem - wymiana myśli pomiędzy nim a Tymieniecką trwała aż do jego śmierci w roku 1970.

Dalsza jej edukacja toczyła się za granicami ojczyzny. W 1951 roku Tymieniecka otrzymała na Sorbonie dyplom études supérieures de philosophie z literatury. Doktoryzowała się w roku 1952 we szwajcarskim Fryburgu. W Szwajcarii poznała Jana Marię Bocheńskiego, który podobnie jak Ingarden był jej wieloletnim przyjacielem. Dzięki niemu wprowadzona została na forum europejskiej filozofii - na przykład w krąg filozofów kierowany przez Jeana Wahla - Le Collége Philosophique w Paryżu. W latach 1951-1952 brała udział w seminarium w Louvain dotyczącym filozofii Edmunda Husserla. Zapoznała się tam z nieopublikowanymi rękopisami tego filozofa, jak również nawiązała współpracę z gronem jego zwolenników.

W latach 1952-1953 kontynuowała studia w Belgii, w Europejskiej Szkole Socjologii i Nauki Politycznej (Sociology and Political Science College of Europe) w Brugii. W latach 1953-1954 habilitowała się na Uniwersytecie Saary w Niemczech.

Następnie Tymieniecka przeniosła się do Stanów Zjednoczonych, gdzie pracowała na wielu amerykańskich uniwersytetach. Wykładała na Uniwersytecie Kalifornijskim w Berkeley (1954-1955), w Yale

„Ruch Filozoficzny” LXVIII (2011) nr 2, s. 433-438Wizerunki filozofów i humanistów polskich. Wiek XX, red. J. Szmyd, Kraków 2000, s. 378-384; Filozofowie wspótcześni. Leksykon, red. J. Szmyd, Bydgoszcz 2003, s. 498-505; A. Szymaniak, A.T. Tymieniecka, [w:] Powszechna encyklopedia filozofii, Lublin 2008, http://www.ptta.pl/pef/pdf/t/tymieniecka.pdf (12.08.2014); A. T. Tymieniecka, Self-presenting, [w:] American phenomenology: Origins and developments, Dordrecht 1989, s. 180-190; taż, The theme - The phenomenology of man and of the human condition; the decade of phenomenological research in the World Phenomenology Institute and its three societies, [w:] The phenomenology of man and of the human condition, ed. tejże, Dordrecht 1983, s. xi-xxv (Analecta Husserliana. The Yearbook of Phenomenological Research, XIV); M. Wietlewska, Nota o autorce, [w:] A. T. Tymieniecka, Życie w petni „logos”. Ksiega I: Metafizyka Nowego Oświecenia, tł. M. Wiertlewska, Poznań 2011, s. 397. 
(1956-1958), w Instytucie Studiów Niezależnych Radcliffe’a w Cambridge, Massachusets (1960-1962), na Uniwersytecie Waterloo, Ontario, Kanada (1969-1970) oraz Uniwersytecie St. Johnsa w Nowym Jorku (1970-1972).

Tymieniecka była dożywotnim prezesem Międzynarodowego Instytutu Wyższych Studiów Fenomenologicznych (The World Institute for Advanced Phenomenological Research and Learning), którego siedziba znajduje się w Hanower, New Hampshire w USA. Przez wiele lat zajmowała się również redagowaniem serii wydawniczej pt. Analecta Husserliana. The Yearbook of Phenomenological Research oraz czasopisma „Phenomenological Inquiry. A Review of Philosophical Ideas and Trends".

Wśród współpracowników Tymienieckiej byli m.in. Hans-Georg Gadamer, Stephen C. Pepper, Alfred Tarski, Rudolf Carnap, Paul Ricoeur, Emmanuel Lévinas oraz Karol Wojtyła. Z przyszłym papieżem pracowała cztery lata nad edycją angielskiej wersji jego Osoby i czynu (The acting person). Przekład ukazał się w tomie 10 Analecta Husserliana, w roku 1979.

Opublikowała wiele artykułów na łamach Analecta Husserliana oraz napisała serię czterech prac Logos and life i dwa tomy The fullness of the logos in the key of life. Czwarty tom Logos and life zatytułowany Impetus and equipoise in the life-strategies of reason oraz tom pierwszy The fullness of the logos in the key of life o tytule The case of God in the new enlightenment zostały przetłumaczone na język polski przez Małgorzatę Wiertlewską. 27 kwietnia 2012 roku wykład Tymienieckiej Możliwość, ontopojetyka życia i potwierdzenie Wszechświata, który odczytał Adam Workowski, był punktem specjalnym 12 Dni Tischnerowskich w Krakowie.

Anna Teresa Tymieniecka zmarła 7 czerwca 2014 roku.

\section{Zarys filozofii Anny Teresy Tymienieckiej}

Filozofia Tymienieckiej została określona przez Jana Szmyda jako optymistyczna ze względu na to, że nie przystaje do modeli filozofii 
propagowanych przez postmodernizm i dekonstruktywizm, a głosi wręcz „pochwałę" filozofii w jej klasycznym wymiarze ${ }^{2}$. Jednocześnie jednak trzeba podkreślić, że optymizm tej filozofii wynika z bezpośredniego odniesienia do kondycji człowieka i ma wymiar metafizyczny.

Anna Teresa Tymieniecka - w ramach idei onto-poiesis - opisuje rzeczywistość jako jedność wszystkiego, co żywe ${ }^{3}$. Opis kondycji człowieka przyjmuje w tym przypadku formę optymizmu ${ }^{4}$. W filozofii Tymienieckiej życie stanowi wyjątkową egzystencjalną sytuację, w której nie tylko człowiek, ale również cały świat żywy dąży do twórczego rozwoju.

W ramach swojej twórczości Tymieniecka stworzyła własny system metafizyczny, który obejmuje studia religii, kosmologii, antropologii, sztuki i kultury. Nazwała go fenomenologią życia i ludzkiej kondycji (Phenomenology of Life and of the Human Condition) - filozofia ta, w oparciu o metodę fenomenologiczną, podejmuje refleksję nad rzeczywistością rozumianą jako onto-poiesis, w której centrum jest kategoria życia ( $w$ wymiarze zarówno egzystencjalnym, jak i biologicznym) oraz kategoria ludzkiej kondycji, będącej najbardziej zaawansowaną formą samoindywidualizacji żywych organizmów w znanym wszechświecie.

Sednem idei onto-poiesis jest koncepcja, że rzeczywistość jest uniwersum istot żywych i jako taka stanowi jedność. O rzeczywistości nie możemy mówić inaczej niż w kategoriach życia - są to jednak kategorie racjonalne. Rzeczywistość powstała bowiem w ramach konstruktywnego poiesis jako efekt funkcjonowania wielu typów logosu w ramach impetu stawania się. Tymienieckiej koncepcja źródła rzeczywistości często porównywana jest do Bergsonowskiego élan vital. Polsko-amerykańska filozof zaznacza jednak, że rzeczywistość nie staje się w sposób

2 J. Szmyd, Międzynarodowy Kongres Filozoficzny dla uczczenia dorobku twórczego A. Tymienieckiej, dz. cyt., s. 436.

Por. L. Pyra, Nature's value and nature's future, [w:] Phenomenology and the human positioning in the cosmos, ed. A. T. Tymieniecka, Dordrecht 2013, s. 174 (Analecta Husserliana. The Yearbook of Phenomenological Research, CXIII).

4 Por. np. A. T. Tymieniecka, Logos and life, Bk. 4: Impetus and equipoise in the life-strategies of reason, Dordrecht 2000, s. xxxiv-xxxvi (Analecta Husserliana. The Yearbook of Phenomenological Research, LXX). 
chaotyczny, jak w koncepcji francuskiego myśliciela, lecz proces ten jest uporządkowany. Życie powstaje w racjonalnej rzeczywistości. Jednocześnie manifestuje się ona jako obiektywny świat żywy, co nie byłoby możliwe, gdyby nie samoindywidualizacja istot żywych, które dokonują obiektywizacji rzeczywistości poprzez akt konstytucji. Jest to jeden z wielu wymiarów aktywności istot żywych, które uczestniczą w procesie twórczym rzeczywistości. Jednocześnie stanowią jej część - istoty żywe nie są jedynie podmiotami, w których świadomości odbywa się akt konstytucji świata, lecz są istotami biologicznymi, przez co są ściśle związane z jego siłami i zasobami. Istota żywa posiada intencjonalną świadomość i organizm, który wzrasta, dążąc do entelechii.

Tymieniecka proponuje refleksję nad miejscem człowieka we wszechświecie oraz sugeruje nową krytykę rozumu, która ustaliłaby nowe kryteria myślenia ${ }^{5}$. Według Tymienieckiej takie kryteria mogłyby być początkiem Nowego Oświecenia ${ }^{6}$ i odnowy ludzkiej kondycji. Proponuje, aby nowym „archimedesowym” punktem filozofii był akt kreatywny świadomości, który stanowi „nić łączącą" różne aktywności umysłu i różne formy racjonalności - bez niego bowiem niemożliwy byłby rozwój człowieka w otaczającym go świecie. Człowiek rozumie otaczającą go rzeczywistość poprzez kreatywne jej przeżywanie. Racjonalność, która zdaniem Tymienieckiej jest jej źródłem, powinna zostać ponownie poddana refleksji na drodze filozoficznej.

Jaka natomiast jest rola samej filozofii w twórczości Tymienieckiej? Filozofia stanowi „ukoronowanie” ludzkiej samoindywidualizacji i jako taka nie tylko pełni rolę środka interpretacji otaczającej człowieka rzeczywistości, lecz w czasach kryzysu myśli humanistycznej (a za takie uważała Tymieniecka przełom XX i XXI wieku) może stanowić przyczynek do odnowy ludzkiej kondycji.

Myślenie i przeżywanie są w filozofii Tymienieckiej nierozdzielne, zatem kategorie życia i filozofii są w jej myśli nieodłączne.

Por. A. T. Tymieniecka, Życie w pełni „logos”, dz. cyt., s. 15-19.

Por. tamże, s. 11-15. 


\section{Akt kreatywny jako radykalna zmiana fenomenologicznej perspektywy}

W celu zrozumienia różnicy pomiędzy założeniami tradycyjnej fenomenologii ${ }^{7}$ a metodą fenomenologiczną, jaką posługuje się Tymieniecka w swojej filozofii, należy odnieść się do problemu rozróżnienia pomiędzy aktem kreatywnym a konstytutywnym w ludzkiej świadomości.

Tymieniecka przeprowadziła w swojej twórczości gruntowną krytykę tradycyjnej fenomenologii - zwłaszcza w odniesieniu do filozofii Husserla ${ }^{8}$ i Ingardena ${ }^{9}$. Jest to $\mathrm{z}$ pewnością temat na odrębną publikację, lecz bez krótkiego odniesienia do tej krytyki nie można zrozumieć natury aktu kreatywnego, a następnie problemu kultury, moralności i duchowości w filozofii polsko-amerykańskiej myślicielki.

Tymieniecka wychodzi z założenia, że fenomenologia ejdetyczna nie może w sposób wystarczający opisać ani świata żywego, ani jednostki żyjącej w jego obrębie, bowiem poprzez opisanie i analizę eidos kolejnych struktur rzeczywistości izolujemy elementy świata żywego i nie jesteśmy w stanie zauważyć natury ich połączenia, przez co stają się jedynie abstrakcyjnymi modelami.

Tymieniecka ceniła wkład Ingardena w krytykę Husserla, jak również jego dokonania na polu estetyki. Uważała jednak, że jego ontologia jest obciążona wadliwym sposobem ujmowania rzeczywistości. Jej zdaniem polski filozof przeprowadzał swoje analizy na poziomie struktur, które były już „owocem” konstytucji poznawczej, a następnie wyabstrahowane. Krytycznie odnosiła się także do jego koncepcji indywiduum,

\footnotetext{
Będę posługiwał się tym terminem tak, jak używa go Tymieniecka - która poprzez tradycyjną fenomenologię rozumie metody fenomenologii transcendentalnej oraz ejdetycznej.

W celu zrozumienia różnych aspektów konstytucji w filozofii Husserla por. np. E. Husserl, Idee czystej fenomenologii i fenomenologicznej filozofii, tł. D. Gierulanka, Warszawa 1967, s. 180-182, 292-296; E. Husserl, Medytacje kartezjańskie, tł. A. Wajs, Warszawa 1982, s. 75-81; A. Półtawski, Świat, spostrzeżenie, świadomość. Fenomenologiczna koncepcja świadomości a realizm, Warszawa 1973, s. 266-272.

W celu zrozumienia różnych aspektów konstytucji w filozofii Ingardena por. np. R. Ingarden, Studia z teorii poznania, red. A. Węgrzecki, Warszawa 1995, s. 114-115, 123-125; A. Półtawski, Realizm fenomenologii, Toruń 2000, s. 248-253, 256, 258-260.
} 
które według niej może działać jedynie w wymiarze idealnym poprzez koegzystencję ejdetycznych struktur. Takie indywiduum musiałoby nieustannie i fundamentalnie zmieniać się, aby móc działać w świecie. W filozofii Tymienieckiej indywiduum jest „zakorzenione” w świecie żywym, a jego egzystencja jest możliwa, ponieważ kształtuje ono swoje osobiste telos. Źródłem egzystencji takiego indywiduum ma być jego zdolność do indywidualizacji i kształtowania swoich możliwości oraz sposobu obecności w świecie, a nie jego istota. Według niej w filozofii Ingardena koncepcja telos jest obecna, lecz irrelewantna.

Podobny wymiar będzie miała krytyka późnej fenomenologii Husserlowskiej, poszukującej opisu struktur wiedzy i doświadczenia na gruncie świadomości transcendentalnej w odniesieniu do logiki i teorii poznania. Zdaniem Tymienieckiej naturą ludzkiego bytowania w świecie żywym jest kreatywność, a nie konstytucja - stanowi to radykalny zwrot fenomenologicznej perspektywy ${ }^{10}$. Nie oznacza to, że twórczość Husserla jest nieprzydatna i nieaktualna - opis transcendentalnej świadomości adekwatnie przedstawia proces konstytucji, jednakże nie wskazuje źródła doświadczenia ludzkiego, którym w filozofii Tymienieckiej jest akt kreatywny. To, co dane człowiekowi, jest zdaniem polsko-amerykańskiej filozof efektem jego samo-indywidualizacji. Ponadto należy wskazać na istotną analogię pomiędzy sposobem, w jaki rzeczywistość jest konstruowana a sposobem, w jaki świadomość konstytuuje rzeczywistość. Logika w filozofii Tymienieckiej ma charakter architektoniczny, tj. stanowi sposób, w jaki konstruowana jest rzeczywistość, a nie wyłącznie fundament poznania. Zredukowanie w filozofii Husserlowskiej pola doświadczenia do świadomości transcendentalnej, zamiast - tak jak w filozofii Tymienieckiej - do ogółu doświadczenia ludzkiego jest jednym z głównych powodów, dla których krytykuje niemieckiego filozofa.

Jak możemy zauważyć, obserwując rozwój kultury, w obrębie naszej świadomości pojawiają się wciąż nowe, twórcze struktury

10 Por. A. T. Tymieniecka, Logos and life, Bk. 1: Creative experience and the critique of reason. Introduction to the phenomenology of life and the human condition, Dordrecht 1988, s. 3-6 (Analecta Husserliana. The Yearbook of Phenomenological Research, XXIV). 
doświadczenia. Zdaniem Tymienieckiej akt konstytutywny świadomości skupia się na stałych wzorcach rzeczywistości - aby możliwa była indywidualizacja jakiejkolwiek istoty żywej, musi pojawić się w jej świadomości akt kreatywny, który stworzy nowe formy i pozwoli na „otwarcie" się na nowe doświadczenie oraz rozwój. U najprostszych organizmów sprowadza się on do odnajdywania nowych sposób przetrwania, lecz u bardziej skomplikowanych wiąże się również z innymi sposobami funkcjonowania w rzeczywistości.

W filozofii Tymienieckiej akt konstytutywny świadomości nie tworzy „zamkniętego” obrazu rzeczywistości, ale uzupełnia pole świadomości o nowe dane i reorganizuje je w odniesieniu do powtarzających się modeli form strukturalnych (models of recurrent structural forms $)^{11}$, których implementowanie w polu świadomości tworzy przekonanie o obiektywności świata. Struktury, które percypujemy, korespondują z analitycznym oglądem rzeczywistości, który odbywa się na poziomie poznania eidoi. Twórczy ogląd rzeczywistości wyraża się raczej poprzez poszukiwanie motywu (theme), a nie istoty - można go zobrazować poprzez sposób, w jaki na przykład malarz patrzy na krajobraz. Ten rodzaj oglądu otwiera możliwość oryginalnego spojrzenia na rzeczywistość i dopuszcza nowy rodzaj doświadczenia. Nie jest to jedynie refleksja nad charakterem zdolności poznawczych człowieka. W filozofii Tymienieckiej również struktury, które konstruuje rozwijająca się rzeczywistość, są „otwarte” na możliwość interpretacji - nie tylko na drodze intencjonalnego oglądu, ale przede wszystkim na drodze indywidualizacji istoty żywej. Jeśli spojrzymy na świat żywy oraz człowieka jako jedność, bez podziału na kategorie: przedmiot i podmiot - będziemy w stanie zrozumieć, czym jest rzeczywistość w filozofii Tymienieckiej ${ }^{12}$. Przede wszystkim podstawowym postulatem jej filozofii jest odnalezienie radykalnego źródła ludzkiego doświadczenia bez odniesienia do ontycznego fundamentu rzeczywistości - jego poszukiwanie jest jej zdaniem absurdalne. Zamiast tego proponuje,

$11 \quad$ Por. tamże, s. 126.

12 Por. tamże, s. 125-128. 
aby jako pierwotne źródło ludzkiej rzeczywistości i doświadczenia człowieka uznać akt kreatywny ${ }^{13}$.

\section{Człowiek i kultura}

Kultura wytworzona przez człowieka jest w swej naturze ontopojetyczna - to znaczy, że uczestniczy w procesie twórczym rzeczywistości i z perspektywy człowieka jest podstawą tego procesu. Człowiek jest istotą, która transcendowała witalny sposób funkcjonowania w świecie, implementując wyobraźnię jako źródło modeli, wykorzystywanych w aranżowaniu świata żywego. W odniesieniu do tych modeli, dzięki użyciu intelektu, woli i pamięci stworzył w świadomości narzędzie samointerpretacji rzeczywistości, stające u podstaw każdego doświadczenia - jest nim kultura.

Kategorię kultury w filozofii Tymienieckiej należy odnieść do jej koncepcji duszy. Dusza (soul) nie jest według polsko-amerykańskiej filozof czymś substancjalnym, stanowi empiryczny wymiar funkcjonowania psyche, wyrażający się w duchu (spirit), którego dziedziną jest religia, sztuka i kultura. Aktywność duszy stanowi „pomost” pomiędzy światem empirycznym a świadomością człowieka - może mieć zarówno wymiar świadomy, jak i podświadomy ${ }^{14}$. Tymieniecka analizuje fenomen duszy z perspektywy onto-poiesis, jako specyficzny rodzaj empirycznej aktywności wszystkich istot żywych, który w przypadku ludzi jest formą uczestnictwa w zobiektywizowanym duchu.

Moralność w sensie obiektywnym funkcjonuje w obrębie ducha, choć z perspektywy każdej odrębnej istoty żywej stanowi sposób przeżywania, który przybiera formę „pasji” (passion) duszy do moralnego postępowania. „Pasje” duszy są to formy duchowej aktywności człowieka, wyrażającej się w empirycznym świecie poprzez dążenie do określonych ideałów i wyobrażeń.

13 Por. tamże, s. 132.

14 Por. A. T. Tymieniecka, Logos and life, Bk. 3: The passions of the soul and the elements in the onto-poiesis of culture, Dordrecht 1990, s. 22. 
Nie byłoby możliwe powstanie kultury, gdyby nie akt kreatywny świadomości człowieka, który pozwala na powstawanie novum w obrębie ludzkiej rzeczywistości. To novum może stanowić dzieło sztuki, jak również nowy sposób zachowania, normę czy narrację - twórczy „pęd” rzeczywistości przejawia się w aktywności twórczej człowieka we wszystkich jej wymiarach, również moralnym. Wytwórczość człowieka przekracza poziom witalny, ale jest w ciąglym odniesieniu do niego - przejawia się to również w kulturze, która jest „odbiciem” spectrum dążeń człowieka jako istoty żywej. Kultura jest „zapisem” ogółu poiesis ludzkości $^{15}$. W związku $\mathrm{z}$ tym nie można powiedzieć, że kultura będzie $\mathrm{w}$ filozofii Tymienieckiej zredukowana całkowicie do zbioru modeli, idei czy symboli - ma ona wyjątkowo duchowy wymiar. W zasadzie bez powstania kultury człowiek nie mógłby być istotą duchową czy moralną. W myśli polsko-amerykańskiej filozof kultura nie stanowi zaprzeczenia ludzkiej egzystencji biologicznej, lecz stanowi raczej jej wypełnienie, które realizuje się poprzez indywidualizację każdej istoty żywej. Popędy, pragnienia, zdolności i idee w obrębie ludzkiej kondycji krystalizują się poprzez kulturę. „Używając literatury jako modelowego przykładu, Tymieniecka bada pochodzenie fundamentów kultury oraz idee i stany (jak czyniła to w swoich poprzednich książkach), które ukazują się na pograniczu świadomości (twilight of consiousness). Tymieniecka broni poglądu, że człowiek jest totalnością ciała i umysłu. W sferze pogranicza świadomości fizjologiczne funkcje wchodzą $\mathrm{w}$ interakcje $\mathrm{z}$ tak zwanymi «wyższymi» funkcjami, które rozwijają się w procesie krystalizacji specyficznej ludzkiej kondycji. Na tym poziomie, ludzka świadomość in statu nascendi uczy się, jak reagować na stymulacje, potrzeby, etc. Czyni to od razu w swój własny, ludzki sposób, na jaki pasje oraz elementy (elements) pełnią podstawową rolę. Najbardziej istotnymi pierwiastkami jest światło (albo przeciwieństwo światła - ciemność) oraz morze"16 - pisze

15 Por. tamże, s. 21.

${ }_{16}$ K. Górniak-Kocikowska, The light, the word, the sea, and the inner moral self, tł. własne, [w:] The elemental dialectic of light and darkness. The passions of the soul in the onto-poiesis of life, ed. A. T. Tymieniecka, Dordrecht 1992, s. 27-28 (Analecta Husserliana. The Yearbook of Phenomenological Research, XXXVIII). 
Krystyna Górniak-Kocikowska. Pierwiastki, czy też elementy (elements) onto-poiesis kultury, takie jak wspomniane powyżej światło oraz morze, stanowią podstawę formy, w jakiej człowiek wyraża swoje dążenia poprzez kulturę - są jednocześnie „pasjami” duszy.

Element morza stanowi szczególny obiekt zainteresowania z perspektywy tematu niniejszego artykułu, gdyż zdaniem Tymienieckiej stanowi moralne „poruszenie” duszy. Polsko-amerykańska filozof odkrywa poprzez analizę metafory morza, że istnieje w obrębie kultury wyobrażenie dramatycznych losów jednostki, która dąży do moralnej postawy w każdej sytuacji życiowej. Można jej zdaniem znaleźć połączenie pomiędzy metaforą morza a podświadomym dążeniem duszy do "bycia autentycznym”, „bycia w zgodzie z prawdziwym sobą" (the passion to be true to one's self), co stanowi kulturowe zarzewie moralności $^{17}$. Bycie człowiekiem moralnym jest jak konfrontacja z morzem, które jest obcą przestrzenią, pozostającą $\mathrm{w}$ ciągłym ruchu, a jednocześnie jest integralne i stanowi rzeczywistość, w której konkretne zachowanie może zapewnić człowiekowi przetrwanie. Kultura jest ontopojetyczna i jako taka stanowi jedność w swoim twórczym charakterze - stąd możemy znaleźć analogię dla postawy człowieka mierzącego się z żywiołem w kontekście duchowym, w którym człowiek moralny konfrontuje się z przestrzenią swojego życia. Moralność nie jest jedynie częścią kultury, lecz specyficznie ludzką postawą wobec świata.

\section{Dobro w filozofii Tymienieckiej}

Dążąc do zrozumienia problemu moralności w twórczości Tymienieckiej, można zaproponować wstępne prześledzenie dziejów wartości dobra w tym systemie myślenia, aby następnie dokonać kolejnych analiz. W tym celu musimy odwołać się do pięciu typów ludzkiego funkcjonowania w rzeczywistości: witalnego, mentalnego, podświadomego, rozumowego i duchowego.

17 Por. A. T. Tymieniecka, Logos and life. The passions of the soul and the elements..., dz. cyt., s. 139. 
W przypadku każdego żywego organizmu możemy mówić o dobru w sensie biologicznym. Każdy organizm żywy ma instynkt przetrwania, który z jego perspektywy - i tylko z jego perspektywy - może zostać określony jako dobro. W przypadku bardziej rozwiniętych organizmów pojawia się chęć symbiozy ${ }^{18} \mathrm{z}$ innymi żywymi istotami w celu zwiększenia prawdopodobieństwa przetrwania. Obydwa instynkty - chęć przetrwania i chęć symbiozy - stanowią podstawę dążenia każdej istoty żywej do dobra, która przybiera odmienne formy w przypadku bardziej skomplikowanych poziomów rozwoju organizmów.

Nawet prymitywny system nerwowy pozwala żywym istotom na dokonanie odpowiedniego wartościowania $\mathrm{z}$ punktu widzenia ogólnie rozumianego interesu organizmu, w ramach którego naczelnym dobrem jest możliwość przetrwania. Spectrum tego wartościowania powiększa się wraz z rozwojem ośrodkowego systemu nerwowego i samoindywidualizacją żywej istoty. Prowadzą one do zwiększenia możliwości adaptacji w środowisku, co z kolei zapewnia większą możliwość przetrwania. Na poziomie rozwoju systemu nerwowego, a bardziej konkretnie na poziomie rozwoju mózgu, możemy mówić o konwersji sensu $\mathrm{z}$ witalnego na kojarzony z aktywnością umysłową. Na tym poziomie kalkulacja możliwości przetrwania, odbywająca się już na poziomie bodziec - reakcja, prowadzi do wyboru. Wybór wiąże się z fenomenem wolności, która jest jedną z podstawowych form manifestacji życia. Być może rozróżnienia pomiędzy instynktem a zaangażowaniem w określony sposób życia, należy szukać już na tym poziomie rozwoju. Zaangażowanie to nie tylko należy wiązać z poszerzonym spectrum wartościowania dotyczącego możliwości przetrwania, ale również z intencjonalnym nakierowaniem na konkretną mentalną wizję, wyobrażenie tej możliwości przetrwania, której powstanie jest możliwe jedynie dzięki aktywności umysłowej większej liczby osobników w ramach jednego gatunku.

Z aktywnością umysłową należy kojarzyć podświadomą aktywność organizmów, którą Tymieniecka łączy z empirycznie doświadczanym

18 Por. taż, Logos and life, Bk. 4: Impetus and equipoise in the life-strategies of reason, dz. cyt., s. $575-576$. 
fenomenem duszy. Moralność, zanim zostanie wyrażona w formie ideałów, wyraża się poprzez transcendowanie naturalnych uwarunkowań teleologicznych istoty żywej. Dążenie do dobra Tymieniecka określa jako pasję człowieka do przezwyciężenia natury poprzez dążenie do konkretnego telos, w którego centrum jest obraz siebie. Obraz ten jest odniesiony do wyobrażeń ludzkości na temat słusznego działania - wyobrażenia te nie mogłyby powstać, gdyby nie uprzednia aktywność umysłowa istoty ludzkiej.

Możemy mówić w tym punkcie o kolejnej konwersji sensu. Powstanie wyobrażenia dobra jako idei, jako wartości per se, należy wiązać się $\mathrm{z}$ wyodrębnieniem ludzkiej kondycji w jej wymiarze idealnym, czyli przekraczającym podświadome dążenia człowieka. Dla Tymienieckiej moralność jest swoistego rodzaju poszukiwaniem stanu równowagi w obliczu nieokreśloności życia, które polsko-amerykańska filozof określa jako „dionizyjską grę"19. Ten stan równowagi może być osiągnięty przede wszystkim poprzez organizację społeczną ${ }^{20}$.

Stan równowagi nie jest jednak tym, co Tymieniecka chciałaby określić jako ethos ${ }^{21}$. Ludzkie życie nie sprowadza się bowiem do racjonalizacji możliwości przetrwania. Z punktu widzenia świadomości człowieka bardziej podstawową jej funkcją nie będzie dla Tymienieckiej akt konstytucji - z którym w pewnej mierze wiąże się poszukiwanie równowagi w manifestującym się świecie - lecz akt kreatywny, który wyraża podstawową aspirację człowieka do transcendowania i do wykraczania poza warunki swojego życia. W tym punkcie wyraża się napięcie pomiędzy ethos a eidos w świadomości człowieka. To ethos staje się istotną częścią kultury, a więc również ludzkiej kondycji, wyrażając dążenie ludzkości do rozwoju. Rozwój ten ściśle związany jest na poziomie idealnym $\mathrm{z}$ kategorią ethos, na poziomie podświadomym natomiast znów można mówić o konwersji sensu - w obrębie ludzkości pojawia się pragnienie przekroczenia naturalnego cyklu życia i śmierci. 
Metafizyczna koncepcja dobra pojawia się w momencie powstania w obrębie ludzkiej kondycji dążenia do transnaturalnego przeznaczenia, pędu ku transcendencji. Telos człowieka zostaje związane z dobrem przekraczającym świat żywy i jako takie wyraża się poprzez religię i filozofię. Moralność jest jedną ze specyficznie ludzkich aktywności, która może otworzyć człowieka na perspektywę metafizyczną - telos człowieka, zanim zwiąże się z transnaturalnym wymiarem ludzkiego działania, może się bowiem wyrażać poprzez moralną postawę wobec świata. Kultura ma w tej koncepcji stanowić zarzewie duchowej działalności człowieka.

\section{Duchowy wymiar aktywności człowieka - pęd ku transcendencji}

Ludzki pęd ku transcendencji wyraża się poprzez ludzkie dążenie do nadania swojemu życiu duchowego wymiaru poprzez przekroczenie powszedniej, bezrefleksyjnej egzystencji, odkrycie skończoności życia i obranie wobec niego odpowiedniej postawy, która ma nadać mu nowy sens. Skierowanie duszy ku jej transnaturalnemu przeznaczeniu odbywa się, zdaniem Tymienieckiej, poprzez trzy jej „poruszenia" (three movements of the soul) ${ }^{22}:, 1$ ) radykalne badanie - przyjęcie pewnej postawy wobec rzeczywistości zewnętrznej (źródłem tego jest podświadome pragnienie rozumienia skłaniające człowieka do intelektualnej refleksji), chęć poznania stanów bytowych, przyczyn zdarzeń, a w ostateczności poznania sensu własnego istnienia. Podmiotem tej analizy jest dusza ludzka. Po uprzednim odrzuceniu wszystkich sądów, naturalnych wartości duszy, następuje szukanie przez duszę nowych punktów odniesienia; 2) dążenie w kierunku «egzaltacji i ideałów», kreacja wartości (społecznych, moralnych, estetycznych, religijnych) pełniących funkcję ideałów - tzw. podświadomych form doświadczenia, umożliwiających twórczy rozwój człowieka; 3) dążenie w kierun$\mathrm{ku}$ transnaturalnego przeznaczenia - ku Transcendencji” ${ }^{23}$. Kultura,

22 Por. A. T. Tymieniecka, Logos and life, Bk. 2: The three movements of the soul, Dordrecht 1988, s. xxxiv-xxxv (Analecta Husserliana. The Yearbook of Phenomenological Research, XXV).

23 A. Szymaniak, A.T. Tymieniecka, [w:] Powszechna encyklopedia filozofii, dz. cyt. 
w ramach której człowiek kształtuje swoją osobowość oraz moralność, pozwalająca na sformułowanie postawy wobec świata i odkryciu duchowego telos, stanowią źródło ludzkiego pędu do transcendowania. Człowiek odkrywa to źródło, kiedy jego dusza odnajduje pełnię $\mathrm{w}$ funkcjonowaniu obiektywnego ducha. Dopiero w ramach takiego doświadczenia pojawia się w filozofii Tymienieckiej autentyczny akt religijny. Boskość manifestuje się w podwójnym aspekcie - ludzkiej immanencji i Boskiej transcendencji ${ }^{24}$. Ludzka immanencja wyraża się poprzez doświadczenie sacrum, natomiast Boska transcendencja poprzez doświadczenie Świadka - Boskości obecnej w życiu, choć radykalnie Innej, transcendującej Naturę. Powyżej nakreślone wątki, dotyczące kulturowego, moralnego i duchowego aspektu funkcjonowania człowieka, stanowią jednocześnie opis „horyzontu”, który człowiek przekracza w momencie przeżycia autentycznego aktu religijnego. Ten aspekt filozofii Tymienieckiej powinien być moim zdaniem przedstawiony w osobnym artykule dotyczącym jej twórczości.

Koncepcja rzeczywistości rozumiana jako onto-poiesis, w której centrum jest specyficznie ludzki wymiar twórczego jej przeżywania, stanowi próbę stworzenia systemu metafizycznego, łączącego różne aspekty funkcjonowania istot żywych w świecie - od witalnego po duchowy. Zdaniem Tymienieckiej pozornie trudne do pogodzenia rodzaje dyskursu, takie jak naukowy czy religijny, mogą zostać poddane pełnej refleksji tylko wtedy, gdy weźmiemy pod uwagę wszystkie sposoby funkcjonowania człowieka w świecie i spectrum jego wytwórczości. Kulturowy, moralny i duchowy wymiar człowieczeństwa nie są odrębnymi elementami ludzkiego doświadczenia - przenikają się one, stanowiąc o totalności ciała i świadomości człowieka w jego kreatywnej naturze.

Tymieniecka opisuje naturę rzeczywistości bez odniesienia do jej ontycznego fundamentu - według niej stanowi to rozwiązanie problemu poszukiwania absolutnej przyczyny, co stanowiło wyzwanie dla różnego typu ontologii na przestrzeni dziejów. Polsko-amerykańska filozof wskazuje raczej na źródło rzeczywistości, a jest nim według niej akt 
kreatywny. Analiza aktu kreatywnego nie tylko pozwala na połączenie różnych wymiarów człowieczeństwa. W dwóch tomach serii dzieł The fullness of the logos in the key of life, napisanych pod koniec jej życia, Tymieniecka wprowadza do swojego systemu fenomen Boga, którego akt kreacji świata - w ramach tak przygotowanego „gruntu” metafizycznego - może stanowić w jej koncepcji źródło rzeczywistości zamiast jej bezpośredniej i absolutnej przyczyny.

Twórczość Anny Teresy Tymienieckiej należy rozumieć jako spójny i otwarty system metafizyczny, który być może jest w stanie przedstawić wiele problemów filozoficznych z nowej perspektywy.

\section{Bibliografia}

Husserl E., Idee czystej fenomenologii i fenomenologicznej filozofii, tł. D. Gierulanka, Warszawa 1967.

Husserl E., Medytacje kartezjańskie, tł. A. Wajs, Warszawa 1982.

Ingarden R., Studia z teorii poznania, red. A. Węgrzecki, Warszawa 1995.

Półtawski A., Realizm fenomenologii, Toruń 2000.

Półtawski A., Świat, spostrzeżenie, świadomość. Fenomenologiczna koncepcja świadomości a realizm, Warszawa 1973.

Tymieniecka A. T., Logos and life, Bk. 1: Creative experience and the critique of reason: Introduction to the phenomenology of life and the human condition, Dordrecht 1988 (Analecta Husserliana. The Yearbook of Phenomenological Research, XXIV).

Tymieniecka A. T., Logos and life, Bk. 2: The three movements of the soul, Dordrecht 1988 (Analecta Husserliana. The Yearbook of Phenomenological Research, XXV).

Tymieniecka A. T., Logos and life, Bk. 3: The passions of the soul and the elements in the onto-poiesis of culture, Dordrecht 1990.

Tymieniecka A. T., Logos and life, Bk. 4: Impetus and equipoise in the life-strategies of reason, Dordrecht 2000 (Analecta Husserliana. The Yearbook of Phenomenological Research, LXX).

Tymieniecka A. T., Życie w petni „logos”. Księga I: Metafizyka Nowego Oświecenia, tł. M. Wiertlewska, Poznań 2011. 